\title{
REPORT
}

\section{A Report of the Third Biennial POLLEN (Political Ecology Network) Conference, 2020}

\author{
Brototi Roy *
}

The POLLEN (Political Ecology Network) Third Biennial Conference 2020 was held on 22-25 September 2020. Initially expected to occur in Brighton, United Kingdom, on 24-26 June 2020, it was later turned into a virtual conference due to the ongoing COVID-19 crisis. The broad theme and title of the conference was Contested Nature: Power, Politics and Prefiguration. Over the four days of the conference, there were about 60 sessions daily, covering a variety of themes and formats, with four interesting keynotes.

The opening keynote plenary was an interesting and relevant discussion on "Political Ecologies of COVID-19" and had researchers and activists sharing experiences and insights on how the pandemic has affected communities and regions differently. The aim was to examine how colonialism, racism, capitalism, and other pre-existing social, political, economic, and historic inequalities have shaped the ways in which the virus has been wrecking differentiated havoc on people and ecologies. The second keynote, co-organized with the Black Ecologies Initiative at Arizona State University, involved the panelists reflecting on the historical and ongoing injustices faced by Black communities as well as their survival efforts despite the multiple types of violence they encounter. The discussion was informed by the panelists' ethnographic and archival work across geographies. The third keynote plenary on "Conservation Futures" discussed ways to make conservation more socially and ecologically just. It drew from multiple theoretical and epistemological strands while

\footnotetext{
* Doctoral Student, Institut de Ciència i Tecnologia Ambientals (ICTA), Universitat Autònoma de Barcelona, Building Z Campus, Z-135, ICTA-UAB, UAB 08193 Bellaterra (Cerdanyola), Barcelona, Spain; brototi.econ@gmail.com.

Copyright (C) Roy 2021. Released under Creative Commons Attribution-NonCommercial 4.0 International licence (CC BY-NC 4.0) by the author.

Published by Indian Society for Ecological Economics (INSEE), c/o Institute of Economic Growth, University Enclave, North Campus, Delhi 110007.
}

ISSN: 2581-6152 (print); 2581-6101 (web).

DOI: https://doi.org/10.37773/ees.v4i1.358 
acknowledging the faults of the current model of conservation-both as a concept and a practice. The fourth and final keynote, called "Troubling Nature and Political Ecology: Feminists in The Capitalocene", was a roundtable discussing feminist political ecology.

Along with these four interesting keynote discussions, there were many diverse sessions on topics such as decentering theories and empirics, epistemes of resistances, and the power of storytelling in political ecology research and activism. The conference also hosted multiple external workshops and events before and during the plenaries and sessions such as an academic-activist world café where people could reflect on their experiences and share skills beyond the Ivory Tower of academia. I coorganized a pre-conference workshop along with Ruth Pinto and Gerardo A. Torres Contreras titled "Is your Political Ecology 'Decolonial'?" to facilitate a space for early-career researchers and/or activists to critically reflect on our praxis.

On the final day of the conference, during the POLLEN assembly, the venue, dates, and theme of the Fourth Biennial POLLEN conference were also announced. The next conference, POLLEN 2022, will be held on 2830 June, 2022, in Durban, South Africa, on the theme "Political Ecology: North, South and Beyond".

Unlike most conferences, POLLEN 2020 did not have a closing plenary. Rather, a decision was taken to "invert" this tradition by inviting all the participants to contribute to a co-produced "reverse plenary". Everyone shared their experiences on Twitter, using the hashtag \#POLLENreverseplenary, which brought to light different experiences of collective sharing and learning. These tweets were then visualized as a word cloud by Michalina Lucja Pietras and Tabea Josephine Dorndorf and shared by POLLEN 2020 organizers.

The online format of the conference allowed for greater diversity in participation. But the inability to see each other's faces, share food and drinks, and have conversations in corridors between sessions was commented about more than once. It was very refreshing to see the representation of young scholars and participants from the Global South in the keynotes; for example, in the first keynote, two of the panelists were $\mathrm{PhD}$ candidates. Discussions on decoloniality, epistemological and ontological justice, and intersectionality frequently occurred during the conference too. It was after these interesting sessions that I felt the absence of a physical conference the most, as it would have allowed me to take the discussion forward after the time for the session was up. 
There were also sessions on publishing in political ecology, the issues that researchers from the Global South face and how can they be countered, as well as broader discussions on the need for open-access journals. In this regard, Ecology, Economy and Society was mentioned as one of the open-access journals, recently launched in India and publishing broadly on socioecological concerns with a focus on South Asia in particular.

In the last keynote, which was on feminist political ecology, some controversial statements on intersectionality were made. It was a bit disconcerting to see a panel that was largely white and completely consisting of researchers based in European institutions be dismissive of a concept that stems from the struggles of African American communities and which has roots in decolonial and queer theories. One of the arguments put forward was that intersectionality is a western concept that should not overshadow feminist concerns. A recent article by Farhana Sultana (2020) was mentioned several times in the discussion by the audience to provide a counter-argument. This article stresses on the need to learn from multiple types of intersectional, interdisciplinary as well as international feminist explorations using varied methodological, epistemological, and pedagogical insights to analyze current socio-ecological injustices.

At the next POLLEN conference to be held in South Africa, I hope to see much more participation and involvement from activists and academics from the Global South in the keynotes. Although it was a commendable idea to have a session on Black ecologies, I wondered about the lack of representation of researchers from the African community as well as institutions in most of the other keynotes; a notable exception was the Conservation Futures plenary. In their short life span, the POLLEN conferences have been a space for critical discussions and reflections. The keynote lecture delivered in the second POLLEN conference on "Critical Approaches to Dispossession in the Melanesian Pacific: Conservation, Voice and Collaboration", seeking the field of political ecology to be more critical and inclusive (West and Aini 2018), was partially answered in the third POLLEN conference. I hope this continues and is amplified in the future, and the next POLLEN conference sees more involvement of scholars and activists living and working in South Asia in particular and the Global South in general, in all spheres of the conference, bringing in a wealth of original ideas and experiences highly relevant for advancing the field of political ecology. 
Ecology, Economy and Society-the INSEE Journal [152]

\section{REFERENCES}

Sultana, F. 2020. "Political Ecology 1: From Margins to Center." Progress in Human Geography, p.0309132520936751. https://doi.org/10.1177/0309132520936751.

West, P., and J. Aini. 2018. "Critical Approaches to Dispossession in the

Melanesian Pacific: Conservation, Voice, and Collaboration." Keynote Lecture, POLLEN 2018 Political Ecology Network Biennial Conference, 19-22 June, Oslo, Norway. https://paige-west.com/2018/07/28/decolonizing-conservation/ 